\title{
An evaluation of teeth of ringed seals (Phoca hispida) from Greenland as a matrix to monitor spatial and temporal trends of mercury and stable isotopes.
}

\author{
Aurore Aubail ${ }^{\text {a, b, * }}$, Rune Dietz ${ }^{\text {a }}$, Frank Rigét ${ }^{\text {a }}$, Benoît Simon-Bouhet ${ }^{\mathrm{b}}$, Florence Caurant ${ }^{\mathrm{b}}$ \\ ${ }^{a}$ National Environmental Research Institute, Aarhus University, Frederiksborgvej 399, P.O. Box 358, DK-4000 \\ Roskilde, Denmark \\ ${ }^{\mathrm{b}}$ Littoral, Environnement et Sociétés (LIENSs), UMR 6250, CNRS-Université de La Rochelle, 2 rue Olympe de \\ Gouges, F-17000 La Rochelle, France \\ * Corresponding author: \\ Tel.: +33 546507629; Fax.: +33 546458264 \\ E-mail address: aaubail@yahoo.fr
}

\begin{abstract}
Total mercury $(\mathrm{Hg})$ concentrations were measured in teeth of ringed seals from Qeqertarsuaq, central West Greenland (1982 to 2006) and Ittoqqortoormiit, central East Greenland (1986 to 2006). Stable isotopic ratios of carbon $\left({ }^{13} \mathrm{C} /{ }^{12} \mathrm{C}\right)$ and nitrogen $\left({ }^{15} \mathrm{~N} /{ }^{14} \mathrm{~N}\right)$ were determined as well to provide insights into diet variations between regions or through time. Mercury concentrations decreased the first years of life of the animals suggesting that $\mathrm{Hg}$ had been transferred from the mother to the foetus and newborn. The $\mathrm{Hg}$ concentrations in teeth were significantly lesser in ringed seals from central West Greenland compared to those from central East Greenland. Carbon and nitrogen stable isotopic values measured in the animals differed also significantly between the two regions. Increasing temporal trends of dental $\mathrm{Hg}$ concentrations between 1994 and 2006 were observed in ringed seals from both central West Greenland and central East Greenland. These increases were attributed to global changes in environmental $\mathrm{Hg}$ levels since no temporal trends in $\delta^{15} \mathrm{~N}$ values were found to support the hypothesis of a diet shift over time. Furthermore, a decreasing temporal trend in $\delta^{13} \mathrm{C}$ values was observed in the teeth of seals from central East Greenland, and explained by a likely change over time towards more pelagic feeding habits; alternatively, the so-known Seuss effect was thought to be responsible for this decrease. Finally it was concluded that the tooth of ringed seal was a good monitoring tissue to assess $\mathrm{Hg}$ trends.
\end{abstract}

Key words: mercury, stable isotopes, carbon, nitrogen, ringed seal, Phoca hispida, teeth, spatial and temporal trends 


\section{Introduction}

Mercury $(\mathrm{Hg})$ is a global contaminant which is emitted to the atmosphere from both natural and anthropogenic sources all around the world (Pacyna and Pacyna, 2002). The important volatility of the elementary form of $\mathrm{Hg}$ allows this metal to be long range transported (Brooks et al., 2005), from its sources of emission to the most remote areas such as the Arctic regions (Pacyna and Pacyna, 2002). The recently discovered phenomenon Atmospheric Mercury Depletion Event demonstrates that the cycle of $\mathrm{Hg}$ in the Arctic is complex, and involves processes at the polar sunrise that lead to the production of bio-available forms of $\mathrm{Hg}$ (Brooks et al., 2005).

Mercury is known to accumulate in organisms and to biomagnify up the food chains (Caurant et al., 1996; Dietz et al., 1996; Rigét et al., 2007). Due to its high position in the marine Arctic food chain and its long life span, the ringed seal (Phoca hispida) accumulates particularly great concentrations of $\mathrm{Hg}$ in its tissues (Dietz et al., 1996, 1998), though with a large variability resulting from biological and ecological influences (Aguilar et al., 1999). This species has a circumpolar distribution and is thought not to be migratory (Maxwell, 1967), although some subadults have been reported to disperse over considerable distances $(>1000$ km), as documented by Reeves et al. (1992) and Kapel et al. (1998). Because of this supposed high degree of site fidelity and its ubiquitous occurrence, the ringed seal is a good candidate for monitoring contaminants for both spatial and temporal trends in Arctic marine food chains, and has therefore been selected by the international AMAP, Arctic Monitoring and Assessment Programme, as an essential monitoring species (AMAP, 2003).

Within the framework of the AMAP and other programmes, samples of ringed seals such as liver, kidney, muscle, and jaws have been collected from the local Inuit subsistence hunting in different regions of Greenland through the last twenty-five years. The liver is the main organ 
for $\mathrm{Hg}$ accumulation in marine mammals including pinnipeds (Wagemann and Muir, 1984), and most studies dealing with $\mathrm{Hg}$ in seals have been carried out on liver among other soft tissues (Dietz et al., 1998; Rigét et al., 2005; Wagemann, 1989).

The tooth is a hard tissue that presents the advantage, compared to soft tissues, to be long term preserved in ancient material, and to provide a good chemical record of life-history events of the individual. Indeed, $\mathrm{Hg}$ is incorporated with other trace elements into the crystalline apatite structure of teeth during their mineralisation (Tvinnereim et al., 2000). As the teeth are relatively stable tissues, the incorporated elements are thought not to be remobilised, or very little, throughout the life of individuals (Eide et al., 1993; Haller et al., 1993; Tvinnereim et al., 2000). Thus, because teeth appear to be excellent archives, they have been investigated for their content of trace elements in rats (Eide and Wesenberg, 1993), marine mammals (Caurant et al., 2006; Outridge et al., 2000, 2002, 2009), and humans (Eide et al., 1993; Tvinnereim et al., 2000), and are considered to be reliable indicators of $\mathrm{Hg}$ exposure (Eide and Wesenberg, 1993; Outridge et al., 2000; Tvinnereim et al., 2000).

Teeth have been used also to measure ratios of the naturally occurring stable isotopes of carbon $\left({ }^{13} \mathrm{C} /{ }^{12} \mathrm{C}\right)$ and nitrogen $\left({ }^{15} \mathrm{~N} /{ }^{14} \mathrm{~N}\right)$, which have demonstrated to provide insights into mammals feeding ecology (Hobson et al., 1997; Hobson and Welch, 1992). The stable isotopic technique is based on the metabolic discrimination between the heavy and the light isotopes. Consumers are enriched in ${ }^{15} \mathrm{~N}$ relative to their food and consequently $\delta^{15} \mathrm{~N}$ measurements serve as indicators of a consumer trophic position (Tieszen et al., 1983). By contrast, $\delta^{13} \mathrm{C}$ values vary little along the food chain and are mainly used to determine primary sources in a trophic network (DeNiro and Epstein, 1978). In the marine environment, $\delta^{13} \mathrm{C}$ values can also indicate inshore versus offshore, or pelagic versus benthic, contribution to food intake (Hobson et al. 1994). The recent combined use of elemental and isotopic measurements appears to be a useful tool for the study of marine mammal ecology (Das et al., 
2003; Hobson et al., 2004) providing information on diet, geography, and trophic transfer of contaminants. Positive correlations between $\delta^{15} \mathrm{~N}$ values and $\mathrm{Hg}$ concentrations have been described within Arctic marine food webs (Atwell et al., 1998; Rigét et al., 2007), suggesting that part of the $\mathrm{Hg}$ variation may be linked to a biomagnification process, and several recent studies have been combining $\mathrm{Hg}$ and stable isotopes measurements to assess feeding variations for marine mammals (Born et al., 2003; Dietz et al., 2004; Hobson et al., 2004).

In this study, total $\mathrm{Hg}$ concentrations and $\delta^{13} \mathrm{C}$ and $\delta^{15} \mathrm{~N}$ values have been determined in teeth of ringed seals from central West and central East Greenland. The aims of this work were: (i) to investigate the influence of biological factors such as gender or age, (ii) to assess potential temporal and spatial trends of $\mathrm{Hg}$ with support provided by the stable isotopes, and (iii) to evaluate tooth as a $\mathrm{Hg}$ monitoring matrix for this species.

\section{Materials and methods}

\subsection{Sampling procedure and preparation}

Tissue samples were obtained from 285 ringed seals collected from the traditional Inuit hunt in Qeqertarsuaq, Disko Bay, located at $69^{\circ} 50^{\prime} \mathrm{N}, 54^{\circ} 00^{\prime} \mathrm{W}$ (central West Greenland, CWG; $\mathrm{n}=115$ ), and in Ittoqqortoormiit, Scoresbysund, located at $70^{\circ} 50^{\prime} \mathrm{N}, 22^{\circ} 00^{\prime} \mathrm{W}$ (central East Greenland, CEG; $\mathrm{n}=170$ ). Sampling took place in May and June, in eight years within the last 25 years (1982 and 1986 for CWG and CEG respectively and 1994, 1999, 2000, 2001, 2002, 2004 and 2006 in common to both regions) (Fig. 1, Table 1). Because of a greater hunting pressure in the Disko Bay area, the sampling was biased, and mainly juvenile seals were obtained from this area. 
Prior to tissue sampling, the animals were measured, and other information such as the date of collection, location, and gender, were recorded. Soft tissues (liver, kidney, muscle) were sampled, and the results of $\mathrm{Hg}$ analyses carried out have been presented partly by Dietz et al. (1998) and Rigét et al. (2004, 2007). In addition, the lower jaws were sampled, and later on went through a maceration process at the Zoological Museum in Copenhagen, Denmark, in order to be totally cleaned from flesh. Then, the bone tissues (mandibles) and the teeth were dried and stored in plastic bags or pap boxes until use.

The age of the animals was determinate at the National Environmental Research Institute (NERI, Roskilde, Denmark), by counting annual layers in the cementum of the canine teeth, after decalcification, thin sectioning $(14 \mu \mathrm{m})$, and staining in toluidine blue as described by Dietz et al. (1991).

The second molar (from the front part) was taken from the lower right mandible for the $\mathrm{Hg}$ analytical purpose $(n=285)$, while the premolar of the same mandible was extracted for the stable isotopes analyses $(n=238)$.

Prior to analysis, each tooth was immersed in $10 \%$ nitric acid for 20 s, and rinsed in several ultra-pure Milli-Q water baths. Teeth samples were dried for a minimum of $24 \mathrm{~h}$ at room temperature, and subsequently stored in cleaned plastic flasks.

\subsection{Analytical procedures and instrumentation for $\mathrm{Hg}$ analyses}

Entire dry molar teeth were analysed for total $\mathrm{Hg}(\mathrm{Hg})$. The $\mathrm{Hg}$ measurements were performed on the whole molar teeth, at the laboratory of the NERI, using a solid sample atomic absorption spectrometer AMA-254 (Advanced Mercury Analyser-254 from LECO, Sweden). The use of this apparatus does not require a chemical pre-treatment which reduces considerably contamination risks or loss of $\mathrm{Hg}$. The analytical process consists in a drying period at $120^{\circ} \mathrm{C}$, prior to a combustion phase at $750^{\circ} \mathrm{C}$ which leads to the desorption of $\mathrm{Hg}$ 
from the samples. Subsequently, the $\mathrm{Hg}$ vapour produced is carried by an oxygen flow to a gold amalgamator, and trapped on its surface. Thereafter, the collected $\mathrm{Hg}$ is released from the amalgamator by a short heat-up to $900^{\circ} \mathrm{C}$, and carried in a pulse through a spectrophotometer, where $\mathrm{Hg}$ is measured by UV absorption. The operating times used for this study, i.e. drying time, decomposition time, and waiting time, were respectively 50, 200, and 45s. The instrument is described in detail elsewhere (Hall and Pelchat, 1997).

As there is no commercial reference material with a matrix similar to teeth or bones and certified for $\mathrm{Hg}$, a reference material was made from two commercial Standard Reference Materials (SRMs), the NIST 1400 Bone ash (National Institute of Standards and Technology, USA), and the DOLT-3 (Dogfish liver from the National Research Council of Canada). The Bone Ash SRM does not contain any $\mathrm{Hg}$ because it has been calcinated at great temperatures, but it brings the similar matrix to calcified tissues, while the DOLT-3 brings the organic matrix and the certified concentration of $\mathrm{Hg}$. The adding of $0.96 \mathrm{~g}$ of DOLT-3 (Certified $\mathrm{Hg}$ concentration of $3.37 \pm 0.14$ in $\mu \mathrm{g} . \mathrm{g}^{-1}$ dry weight) to $31.39 \mathrm{~g}$ of Bone Ash leads theoretically to a $\mathrm{Hg}$ concentration of $0.100 \pm 0.004 \mu \mathrm{g} \cdot \mathrm{g}^{-1}$ dry weight.

The calibration of the customised reference material has been carried out through two different techniques (AMA-254 and cold-vapour Atomic Absorption Spectrophotometry on a Perkin Elmer FIMS 100) in NERI. Moreover, an inter laboratory comparison was carried out for AMA-254 analysis between NERI and CCA (Centre Commun d'Analyses, University of La Rochelle, France). The measurement results of the customised reference material show a good accuracy (i.e. ratio between the recovery measured concentration and the theoretical concentration) of $102 \%$, and a relative standard deviation of $6.3 \%$ (Table 2).

The analytical quality of the $\mathrm{Hg}$ measurements by the AMA-254 was ensured by including the customised reference material mentioned above at the beginning and at the end of each 
analytical cycle of 10 samples. The $\mathrm{Hg}$ measurements of this reference material were in good agreement with the assigned concentration (accuracy of $103.6 \%$ and relative standard deviation of $5.6 \%$ for $\mathrm{n}=80$ ).

The laboratory at NERI participates in the international inter-laboratory comparison exercises conducted by the EEC (QUASIMEME), and the latest 2007 results concerning analyses by AMA-254 were satisfactory $(0<\mathrm{z}<0.5)$.

All data are presented on a dry weight basis (dw), and the detection limit is $0.01 \mathrm{ng} \cdot \mathrm{g}^{-1} \mathrm{dw}$.

\subsection{Analytical procedures and instrumentation for stable isotope measurements}

Each entire premolar was crushed into small pieces before being ground into homogenous powder using a ball mill (Retsch MM2000) for 2 minutes and the amplitude of 90 . Then, powder was stored in small glass flasks. Carbonates of the teeth were removed by digesting the teeth with approximately $1 \mathrm{~mL}$ of a $4 \mathrm{M}$-hydrochloric acid solution at $45^{\circ} \mathrm{C}$ for $48 \mathrm{~h}$. The digested contents were taken up in milli-Q ultrapur quality water, and homogenised before freezing to $-20^{\circ} \mathrm{C}$. Then, the samples were frozen at $-80^{\circ} \mathrm{C}$ for a short time before freezedrying. Finally, an aliquot of each homogenised dried sample was taken, weighted, and loaded into tin capsules. Out of 285 individuals, only 238 samples were available for stable isotope analysis.

Relative abundance of stable isotopes of carbon $\left({ }^{13} \mathrm{C}\right.$ and $\left.{ }^{12} \mathrm{C}\right)$ and nitrogen $\left({ }^{15} \mathrm{~N}\right.$ and $\left.{ }^{14} \mathrm{~N}\right)$ were determined with an elemental analyser connected on-line to an isotope-ratio mass spectrometer (Micromass, Manchester, UK). Stable isotope results are expressed in delta notation $(\delta)$, defined as the part per thousand (\%o) deviation from a standard material:

$\delta^{13} \mathrm{C}$ or $\delta^{15} \mathrm{~N}=[($ Rsample / Rstandard $)-1] \times 10^{3}$, where $R$ is ${ }^{13} \mathrm{C} /{ }^{12} \mathrm{C}$ or ${ }^{15} \mathrm{~N} /{ }^{14} \mathrm{~N}$ 
where Rsample and Rstandard are the fractions of heavy to light isotopes in the sample and standard, respectively. The international standards are the Pee Dee Belemnite (PDB) marine fossil limestone formation from South Carolina for $\delta^{13} \mathrm{C}$, and atmospheric nitrogen for $\delta^{15} \mathrm{~N}$.

\subsection{Data treatment}

Prior to the statistical analyses, the $\mathrm{Hg}$ data $(\mathrm{n}=285)$ were logarithmic-transformed (base e) to reduce skewness, and fit parametric requirements. Shapiro-Wilk and Bartlett test were applied to test the assumptions of parametric tests, such as analysis of variance (ANOVA) and linear regression analysis. In few cases, the assumptions were not fulfilled because of a couple of high $\mathrm{Hg}$ concentration values. However, ANOVA tests are robust to small deviations of the data from the normal distribution (Zar, 2009).

Standard parametric tests such as Pearson's correlation analysis, linear regression analysis, and ANOVA, were applied to test for the influence of factors (i.e. age, gender, location, and year) on the Log-transformed $\mathrm{Hg}$ concentrations or on the stable isotopic values. If the first runs of ANOVA test showed no significance of the interaction between two factors, the interaction factor was removed, and the test re-run.

The relationship between age and dental $\mathrm{Hg}$ concentrations or stable isotopic values were evaluated for each region with a scatterplot using LOWESS (Locally weighted polynomial regression) smoothing. In the same way, the analyses of temporal trends of $\mathrm{Hg}$ and stable isotopic values first were evaluated with scatterplots using LOWESS smoothing separately for each region, thus Log-linear regression analysis was applied to describe the linear component, and tested by means of an ANOVA.

The significance level was set to $\mathrm{p}=0.05$.

The statistical analyses were performed using the free software $R$, version 2.1.1 ( $R$ Development Core Team, 2008). 


\section{Results}

3.1. Concentrations of $\mathrm{Hg}$ in molar teeth and influence of the biological factors, gender and age

Dental $\mathrm{Hg}$ concentrations ranged from 0.43 to $10.99 \mathrm{ng} . \mathrm{g}^{-1} \mathrm{dw}$ for ringed seals from CWG and from 0.95 to $57.6 \mathrm{ng} \cdot \mathrm{g}^{-1} \mathrm{dw}$ for animals from CEG. Arithmetic mean ( \pm standard deviation) was of $2.94 \pm 1.99 \mathrm{ng} \cdot \mathrm{g}^{-1} \mathrm{dw}$ for CWG and $5.75 \pm 6.20 \mathrm{ng} \cdot \mathrm{g}^{-1} \mathrm{dw}$ for CEG. Details for each location and sampling year are reported in Table 1 . The coefficients of variation of dental $\mathrm{Hg}$ concentrations were very high for the CEG seals collected in 1999 (191\%) and 2006 (197\%) (due to two individuals displaying great $\mathrm{Hg}$ concentrations in those years, $49.5 \mathrm{ng} . \mathrm{g}^{-1} \mathrm{dw}$ and $57.6 \mathrm{ng} . \mathrm{g}^{-1} \mathrm{dw}$, respectively), while they ranged from 21 to $74 \%$ for the other years for both regions.

No gender-related difference in dental $\mathrm{Hg}$ concentrations was observed (one-way ANOVA, $\mathrm{p}$ $=0.726)$, hence this parameter was discharged as a variable in the further statistical treatment. The mean age was significantly lesser in seals from CWG (2.7 years old) than in seals from CEG (6.0 years old) (see Table 1) (One-way ANOVA, p < 0.001). Furthermore, no significant difference in mean age was observed for seals in CWG through the years (One-way ANOVA, $\mathrm{p}=0.056)$ whereas the mean age differed significantly among sampling years of the ringed seals from CEG (One-way ANOVA, p = 0.028), with the greatest mean ages in 1986 and 2006, and the lowest in 2000 and 2004.

The plot smoother showed a clear non-linear relationship between age and $\mathrm{Hg}$ concentrations, with a decreasing trend in dental $\mathrm{Hg}$ concentrations for the first 5-7 years of age of the individuals from both regions (Fig. 2). The slope seemed thereafter to level off in older individuals, and a plateau is reached. Therefore the Linear Regression Model was run on two 
age groups of ringed seals, juveniles up to 5 years old and adults above 5 years old. The models showed that there was a significant regression between age and the Log-transformed Hg concentrations for the juveniles $(\leq 5$ years old $)$ from both $\mathrm{CWG}(\mathrm{p}<0.001)$, and CEG $(\mathrm{p}=$ 0.024), with a steeper decrease observed for the West Greenland seals. However, no linear relation was found for adults from CEG $(\mathrm{p}=0.961)$, while too few adults were available to test the age relationship for adult ringed seals from CWG.

\subsection{Stable isotopes in teeth, influence of gender and age, and relation between elemental and} isotopic values

Stable isotopic ratios of carbon and nitrogen determined in the ringed seal teeth exhibited respective mean values of $-16.04 \pm 0.52 \%$ and $16.35 \pm 0.99 \%$ for CWG, and $-17.23 \pm 0.53 \%$ o and $14.90 \pm 1.14 \%$ for CEG (range of values, see Table 3 ). Both ratios were correlated across all individuals $(r=0.4, p<0.001)$, but not when investigating CWG and CEG data separately. Gender was shown to have no influence on the stable isotopic values, neither for $\delta^{13} \mathrm{C}$ (Oneway ANOVA, $p=0.74)$ nor for $\delta^{15} \mathrm{~N}(\mathrm{p}=0.35)$. However, age was correlated significantly with both $\delta^{13} \mathrm{C}$ and $\delta^{15} \mathrm{~N}$ values for seals from $\mathrm{CWG}(\mathrm{r}=0.25, \mathrm{p}<0.05$ and $\mathrm{r}=-0.29, \mathrm{p}<0.05$, respectively), and with $\delta^{13} \mathrm{C}$ values for seals from CEG $(\mathrm{r}=0.42, \mathrm{p}<0.001)$ (Fig. 2). The $\delta^{15} \mathrm{~N}$ age trends were observed on the graphs to be quite similar to the $\mathrm{Hg}$ ones while the $\delta^{13} \mathrm{C}$ relation with age showed an opposite trend to the $\mathrm{Hg}$ and $\delta^{15} \mathrm{~N}$ ones.

Log-transformed $\mathrm{Hg}$ concentrations and $\delta^{13} \mathrm{C}$ and $\delta^{15} \mathrm{~N}$ values were not correlated for the ringed seals from both $\mathrm{CWG}(\mathrm{p}=0.15$ and $\mathrm{p}=0.21$, respectively) and CEG $(\mathrm{p}=0.20$ and $\mathrm{p}=$ 0.87, respectively), when the two regions were studied separately. However, when CWG and CEG data were pooled, relations between Log-transformed $\mathrm{Hg}$ concentrations and $\delta^{13} \mathrm{C}$ values $(\mathrm{p}<0.001)$, and Log-transformed $\mathrm{Hg}$ concentrations and $\delta^{15} \mathrm{~N}$ values $(\mathrm{p}<0.01)$, were found to be significant. 
These statistical results are summarised in Table 4.

\subsection{Spatial and temporal trends}

Although the plot smoother showed an overall decreasing trend in dental $\mathrm{Hg}$ concentrations for the first 5 to 7 years of age of the seals from both regions, the $\mathrm{Hg}$ concentrations measured in the first two years of life of the animals were observed to be quite stable. Therefore, in order to limit the age effect and to avoid the overlapping of the life periods of the seals, we decided to focus on the dental $\mathrm{Hg}$ concentrations of the youngest individuals, up to 2 years old, when assessing the spatial and temporal trends of $\mathrm{Hg}$ concentrations and stable isotopic ratios.

A spatial difference in $\mathrm{Hg}$ concentrations was found (Two-factor nested ANOVA (location nested sampling year), $\mathrm{p}<0.001)$, with significantly greater concentrations in the seals from CEG compared to CWG (Table 1). However, this spatial trend was not consistent among years $(\mathrm{p}<0.001)$.

Stable isotopic values differed significantly between regions, with both greater $\delta^{13} \mathrm{C}(\mathrm{p}<$ $0.001)$ and $\delta^{15} \mathrm{~N}$ values $(\mathrm{p}<0.001)$ in CWG compared to CEG (Table 3). However, while the spatial trend in $\delta^{13} \mathrm{C}$ was consistent over time $(\mathrm{p}=0.071)$, this was not found to be the case for the spatial trend in $\delta^{15} \mathrm{~N}$ values $(\mathrm{p}=0.039)$.

The temporal trends of dental $\mathrm{Hg}$ concentrations of ringed seals are shown on Fig. 3. The temporal trends were very similar for both regions, with an apparent decrease of $\mathrm{Hg}$ concentrations until the 1990's, followed by an increase until 2006, although the Hg dental concentrations of CEG seals were actually lesser in 2006 than in 2004. A Linear Regression 
Model was applied between 1994 and 2006 for seals from both CWG and CEG, and revealed a significant increase of dental $\mathrm{Hg}$ concentrations for this period in seals from both regions ( $\mathrm{p}$ $<0.001$ and $\mathrm{p}=0.018$, respectively).

Concerning the stable isotopes, the $\delta^{13} \mathrm{C}$ values of the ringed seals from CEG were showed to follow a significant decrease over time (4.7\% per year, $\mathrm{p}<0.001$, Fig. 3 ), while $\delta^{15} \mathrm{~N}$ values found in those animals were not $(\mathrm{p}=0.65)$. Finally, neither $\delta^{13} \mathrm{C}$ nor $\delta^{15} \mathrm{~N}$ values of the ringed seals from CWG did follow a temporal trend ( $\mathrm{p}=0.10$ and $\mathrm{p}=0.81$, respectively).

\section{Discussion}

\subsection{Influence of age on $\mathrm{Hg}$ concentrations in teeth}

Mammalian teeth are composed of hydroxyapatite $\mathrm{Ca}_{10}\left(\mathrm{PO}_{4}\right)_{6}(\mathrm{OH})_{2}$, and comprise three types of structures, i.e. cementum, dentine, and enamel. Cementum and dentine grow in well defined layers throughout life, and those layers are known to deposit annually in marine mammals (Miyazaki, 2002). Mercury is believed to be deposited directly from the blood supply or the dentinal tubules into actively growing increments (Haller et al., 1993), and not to be remobilised throughout life of individuals (Eide et al., 1993; Tvinnereim et al., 2000). Despite a low affinity of $\mathrm{Hg}$ for the teeth, previous studies have demonstrated that this element can be measured reliably in teeth (Eide and Wesenberg, 1993; Tvinnereim et al., 2000). The dental $\mathrm{Hg}$ concentrations found in our study appear to be in the same order of magnitude than those reported in the current literature for marine mammals, i.e. ringed seal, with $\mathrm{Hg}$ mean values \pm sd of $4.4 \pm 1.7$ to $8.6 \pm 3.7 \mathrm{ng} . \mathrm{g}^{-1} \mathrm{dw}$ in animals $5-25$ years old (Outridge et al., 2009), walrus (Odobenus rosmarus rosmarus), with $\mathrm{Hg}$ concentrations under 2 ng. $\mathrm{g}^{-1} \mathrm{dw}$ (Outridge et al., 2002), and beluga (Delphinapterus leucas), with $\mathrm{Hg}$ mean values 
$\pm \mathrm{sd}$ of $70.92 \pm 45.35 \mathrm{ng} . \mathrm{g}^{-1} \mathrm{dw}$ (Kinghorn et al., 2008) and $98.4 \pm 109 \mathrm{ng} . \mathrm{g}^{-1} \mathrm{dw}$ (Outridge et al., 2002).

However, the trends of dental $\mathrm{Hg}$ concentrations with the age, described in the literature and in the present study, differ. Indeed, Outridge et al. (2009) found that Hg concentrations measured in the canine tooth (two upper thirds) of Canadian ringed seal was correlated positively with the age of the animal, whereas, in contrary, a significant decrease of dental $\mathrm{Hg}$ concentrations was observed the first years of life for the ringed seals in our study $(\mathrm{p}<0.001$ for CWG, and p = 0.024 for CEG; Fig. 2). In addition, Outridge et al. (2000) showed that Hg concentrations in the tooth cementum increase with the age in beluga whales, while Kinghorn et al. (2008) did find no significant relation between age and $\mathrm{Hg}$ concentrations in the same tissue for the same species. Finally, Outridge et al. (2002) reported an absence of correlation between age and cementum $\mathrm{Hg}$ concentrations in the walrus.

From this literature overview on the dental $\mathrm{Hg}$ in marine mammals, it seems that age accumulation of the $\mathrm{Hg}$ concentrations in the teeth differs within species (in relation to their dentition development), but also with the part of tooth (dentine, cementum or the entire tooth) or even the type of tooth (molar or canine, which may grow at distinct times during the dentition development) on which the $\mathrm{Hg}$ measurements are carried out.

Moreover, as marine mammal exposure to $\mathrm{Hg}$ occurs mainly via food (Aguilar et al., 1999), the variation in dental $\mathrm{Hg}$ concentrations throughout life is expected to be related to changes in dietary regime with age. Ringed seals are diverse feeders on planktonic, nektonic, and benthic organisms, with a diet ranging from pelagic amphipods to different fishes, as polar cod (Boreagadus saida) or Arctic cod (Arctogadus glacialis) in the Greenland waters (Siegstad et al., 1998). Occasionally, immature ringed seals explore the water column down to 
the sea floor, and spend much of their time foraging at depths shallower than 50m (Born et al., 2004), showing a larger preference for crustaceans than adults (Holst et al., 2001).

Furthermore, the diving capabilities of ringed seals increase with age, so that older and larger seals dive in general deeper than younger seals, consuming potentially more fish like polar cod while reducing the consumption of crustaceans (Holst et al. 2001; Reeves et al., 1992). However, this foraging behaviour does not explain why adults have lesser $\mathrm{Hg}$ concentrations compared to juvenile ringed seals. Crustaceans contain lesser $\mathrm{Hg}$ concentrations than fishes in Greenland waters (Dietz et al., 1996), and therefore, a greater crustacean intake of the younger individuals can not be responsible for greater $\mathrm{Hg}$ concentrations in teeth of juveniles compared to adult seals. In addition, the significant negative correlations found between age and $\delta^{15} \mathrm{~N}$ values, for CWG individuals and for all ringed seals (Table 4, Fig. 2), do not match with the above mentioned crustacean-diet for juveniles and fish-diet for adults. Since the mineralisation of the permanent dentition occurs at the foetal stage for the ringed seal (Reeves et al., 1992; Stewart et al., 1998), a consistent explanation to both great Hg concentrations and $\delta^{15} \mathrm{~N}$ values for the first years of life would be the dietary inputs from the mother during the period of gestation and lactation. Indeed, $\mathrm{Hg}$ is known to be transferred from the mother, to the foetus through the placenta, and to the newborn via milk (Grandjean et al., 1994). Both transfers have been reported previously for seals, showing a more quantitatively significant Hg acquisition during the prenatal stage, compared to the postnatal one (Wagemann et al., 1988).

Furthermore, the enriched $\delta^{15} \mathrm{~N}$ values, measured in the first years of age, tend to support the hypothesis of these maternal transfers. Indeed, $\delta^{15} \mathrm{~N}$ of a consumer are related to those of its prey (DeNiro and Epstein, 1978), and an enrichment of $\delta^{15} \mathrm{~N}$, of the order of 3\%o generally, occurs at each trophic transfer (Hobson and Welch, 1992). Thus, the enriched $\delta^{15} \mathrm{~N}$ values displayed by the youngest seals would reflect their consumer position relative to their 
mothers. Similarly to our results, enriched $\delta^{15} \mathrm{~N}$ values in the early life have been previously reported in the teeth of other marine species, such as Steller sea lion (Eumetopias jubatus) (Hobson and Sease, 1998), longbeaked common dolphin (Delphinus capensis) (Nino-Torres et al., 2006), and narwhal (Monodon monoceros) (Dietz et al., 2004). In addition, the depleted $\delta^{13} \mathrm{C}$ values observed in teeth of youngest individuals (Fig. 2) also corroborate the idea of a maternal transfer to foetus and young of the year. Indeed, body fat has been shown to be depleted in ${ }^{13} \mathrm{C}$ compared to other animal tissues due to selective fractionation (Tieszen et al., 1983), and the depleted $\delta^{13} \mathrm{C}$ values of the juvenile seals may reflect likely the mobilisation and the transfer of the carbon from maternal lipid stores, for the foetal development and milk production (Dehn et al., 2007; Polischuk et al., 2001). The same $\delta^{13} \mathrm{C}$ trend has been described previously by Hobson and Sease (1998) in the teeth of Steller sea lions, and explained by the transfer of maternal body lipids during the nursing period.

Following the great $\mathrm{Hg}$ concentrations observed in the teeth in early life, $\mathrm{Hg}$ concentrations are observed to drop for individuals from both regions (Fig. 2). This age $\mathrm{Hg}$ trend can be explained by a progressive "dilution" of the dentine deposited at the foetal and weaning stages by the addition of new post weaning dentine. In addition, the deposition of dentine, and its subsequent mineralisation, reduces the pulp area, and in some species, the pulp cavity becomes occluded at some point with subsequent suspension of dentinal accumulation (Hohn, 2002). Thus, the plateau of $\mathrm{Hg}$ concentrations reached around 10 years old could actually reflect the time of the tooth occlusion. Indeed, up to 15-20 dentinal layers have been observed previously in the canines of ringed seals (Stewart et al., 1996), and the molars being smaller than canine teeth, it is likely that their occlusion would occur earlier in life.

\subsection{Spatial variations of dental Hg concentrations in Greenland}


As a general trend, $\mathrm{Hg}$ concentrations in teeth of ringed seals from Ittoqqortoormiit (CEG) were found to be significantly greater than those from Qeqertarsuaq (CWG). The same spatial difference in $\mathrm{Hg}$ concentrations between CEG and CWG has been reported previously for $\mathrm{Hg}$ concentrations in livers of ringed seals (Dietz et al., 1998; Rigét et al., 2005). Such a spatial variation can be caused by either differences in diet or differences in $\mathrm{Hg}$ concentrations in the environment among seals of both regions.

Feeding habits of the ringed seal have been documented to vary both spatially and temporally (Reeves et al., 1992; Siegstad et al., 1998), which makes difficult to estimate the dietary Hg exposure of the ringed seals. However, differences in diet have been previously suggested by Dietz et al. (1998), as a likely reason for such a spatial difference in $\mathrm{Hg}$ concentrations in ringed seals. In a study on stomach content of Greenland ringed seals, Siegstad et al. (1998) found both arctic and polar cods (65\% by weight) to be important food items of this species in the area of Kong Oscars Fjord (CEG), while capelin (Mallotus villosus) and redfish (Sebastes spp.) (52.2 and 25.2\% weight, respectively) have been reported to be among the main food items in the diet of ringed seals from Qeqertarsuaq area (CWG). Nevertheless, it is worth mentioning that these diets may only reflect seasonal preys since they have been determinate from seal stomachs collected in spring for the CWG individuals, and in summer for the CEG ones. Møller (2006) investigated stable isotopes in the CWG food webs and reported greater $\delta^{15} \mathrm{~N}$ values for both Cottidae, arctic and polar cods, than for capelins or redfishes. Thus, although arctic cod exhibits a greater $\mathrm{Hg}$ content than other Greenland fish species (Dietz et al., 1996), which would have explained the greater $\mathrm{Hg}$ concentrations in teeth of ringed seals from the CEG, our $\delta^{15} \mathrm{~N}$ isotopic data are paradoxically not in agreement with this difference in diet among seals from both areas, since $\delta^{15} \mathrm{~N}$ values were lesser in CEG seals (Cottidae consumers) than in those from CWG (Table 3). On the contrary, $\delta^{15} \mathrm{~N}$ values in teeth would be 
the diet's signature of the entire life of the individual. Thus, on a long time period, the seals would be more exposed to $\mathrm{Hg}$ in the CEG by eating at lower trophic levels, which implies that the food webs would be more contaminated in the CEG than in the CWG.

Stable isotopes of carbon provide information about the sources of primary productivity in ecosystems where distinct isotopically sources are present (for example phytoplankton vs. ice algae). Indeed, the ${ }^{13} \mathrm{C}$ enrichment of benthic compared to planktonic algae is substantial enough to allow distinguishing between benthic and planktonic food sources for coastal animals (France, 1995); so that the more depleted $\delta^{13} \mathrm{C}$ values found in CEG seals could suggest a more pelagic diet for these animals compared to the CWG ones. But most likely, this difference in $\delta^{13} \mathrm{C}$ values can be attributed to distinct oceanography and characteristic spatial $\delta^{13} \mathrm{C}$ values of two different ecosystems. Indeed, the West Greenland area is influenced by a mixture of waters from the cold East Greenland Current and the warmer and more saline Irminger Current (a side branch of the Gulf stream, North Atlantic current), while the East Greenland is dominated by the East Greenland Current that brings cold low-saline polar water south along the eastern coast of Greenland (Born et al., 2003). Previously, the temperature has been described as an important factor of variation of $\delta^{13} \mathrm{C}$ (Rau et al., 1982), resulting in a ${ }^{13} \mathrm{C}$ depletion with high latitudes. Thus, the warmer temperatures of the western Greenland waters may likely lead to more enriched $\delta^{13} \mathrm{C}$ values of the $\mathrm{CWG}$ food web, and explain the greater $\delta^{13} \mathrm{C}$ values found in the tissues of CWG ringed seals compared to the CEG ones.

Mercury is known to be transported on long distance in the atmosphere, and Pacyna and Keeler (1995) described Europe, Asia and North America as the regions where are located most global and regional anthropogenic emissions of $\mathrm{Hg}$ with potential impact on the Arctic environment. The seasonal variability in long-range atmospheric transport to Greenland has been well demonstrated (Kahl et al., 1997), and the influence of this transport may vary 
regionally, result in spatial differences in the deposition of atmospheric $\mathrm{Hg}$, and subsequently, contribute to the spatial differences in $\mathrm{Hg}$ concentrations in the regional ecosystems of Greenland. However, it has also been reported that some natural geological formations may actually contribute substantial amounts of $\mathrm{Hg}$ to the surrounding environment (Painter et al., 1994). Thus, spatial differences in $\mathrm{Hg}$ concentrations found in seals and other marine mammals in the global Arctic have been thought to be related directly to the natural input from underlying geology (Rigét et al., 2005; Wagemann et al., 1995). In the same way, the distinct basement rock between CEG and CWG (Watt and Thrane, 2001) could lead to a different natural input of $\mathrm{Hg}$.

\subsection{Temporal trends of $\mathrm{Hg}$ concentrations in teeth}

Significant increases in $\mathrm{Hg}$ concentrations were found in teeth of ringed seals from both regions between 1994 and 2006, although for CEG, the dental Hg concentrations of the animals were actually lesser in 2006 than in 2004 (Fig. 3). An increase in Hg concentrations in CWG region has been reported previously in liver of ringed seals for the period of 1999 to 2004 (Rigét et al., 2007). The authors did attribute this increase to likely changes in the feeding behaviour of the animals that they investigated through stable isotopes analysis in muscle tissues. However, the increase was not significant anymore when the period was extended from 1994 to 2004. In addition, no temporal trend was detected in ringed seals from CEG, although some year-to-year differences were observed (Rigét et al., 2004).

Mercury concentrations have been shown to increase with trophic levels $\left(\delta^{15} \mathrm{~N}\right)$ in Arctic marine food web (Atwell et al., 1998). In our study, the $\delta^{15} \mathrm{~N}$ analyses, which allow investigation of dietary shifts through time, did exhibit no temporal trends neither for the CWG nor for the CEG ringed seals (Fig. 3), so that a change in diet can not be a consistent explanation for the temporal variations of dental $\mathrm{Hg}$ concentrations. However, it can not be 
excluded that the shift in diet may not be reflected through the $\delta^{15} \mathrm{~N}$ values, since changes in prey species do not imply necessarily changes in trophic level. Nevertheless, we did observe a significant decreasing temporal trend in $\delta^{13} \mathrm{C}$ values in the teeth of seals from CEG (Fig. 3). Since pelagic consumers tend to be more depleted in ${ }^{13} \mathrm{C}$ compared with littoral consumers (France, 1995), this decreasing trend in $\delta^{13} \mathrm{C}$ values over time could likely result from a change toward a more pelagic feeding behaviour of the ringed seals. Alternatively, the decrease of $\delta^{13} \mathrm{C}$ values over time could reflect the dissolution of isotopically light carbon from anthropogenic $\mathrm{CO}_{2}$ in the ocean, the so-known Seuss effect (Quay et al., 1992), which results in a reduction of the oceanic $\delta^{13} \mathrm{C}$ values, and subsequently, in animal tissues. This isotopically light carbon has been released largely to the atmosphere through the combustion of fossil fuels (Quay et al., 1992), and previous studies on teeth of fur seal and ringed seal have revealed a similar decrease in $\delta^{13} \mathrm{C}$ over a century (Newsome et al., 2007; Outridge et al., 2009).

The United States, Europe, Asia and Canada are considered to be the main sources of polluted air reaching Greenland (Boutron et al., 1998). Although $\mathrm{Hg}$ anthropogenic emissions to the atmosphere from Europe and United-States have been reduced recently, the Asian $\mathrm{Hg}$ emissions have been reported to increase substantially these last decennials, especially from China and India, and mainly to be due to the burning of fossil fuels (Pacyna and Pacyna, 2002). A work carried out by Kahl et al (1997) on air mass trajectories to Greenland emphasised the importance of Asian sources. Thus, the recent Hg increase observed in teeth of ringed seals from Greenland may originate for example, from an increase of $\mathrm{Hg}$ emissions from coal combustion partly from China, and subsequent long-range transport of $\mathrm{Hg}$ to Greenlandic regions. 


\section{Conclusion}

The present study outlines the important contribution of the prenatal period to the transfer of $\mathrm{Hg}$ to the teeth of the ringed seal. Age has been shown to influence $\mathrm{Hg}$ concentrations in juvenile seals with a significant decrease during the first 5 years. Although teeth exhibited much lower $\mathrm{Hg}$ concentrations than concentrations generally encountered in soft tissues, they appeared to be a good monitor of $\mathrm{Hg}$ environmental exposure, showing significant differences in $\mathrm{Hg}$ concentrations between both regions and pointing out the increasing temporal trends of Hg concentrations between 1994 and 2006. The ability to investigate temporal trends or to compare geographical areas is useful in the cases where soft tissues are not available. Moreover, teeth constitute a preserved material in which pre-historic temporal trends of trace elements can be measured. However, the results and the comparison with literature also outline the uncertainties and difficulties for interpreting the concentrations and for using such material (e.g. unknown age or type of tooth) as a bio-monitoring media of $\mathrm{Hg}$. Finally, the combined use of the elemental and isotopic analyses provided important complementary information to conclude about the life exposure history of the animals.

\section{Acknowledgement}

This study was partly financed by The Dancea Programme and KVUG (Kommissionen for Videnskabelige Undersøgelser i Grønland). In addition, the Poitou-Charentes region and the Fund M.L. Furnestin-Faure have been contributed financially to this $\mathrm{PhD}$ work. We thank the numerous persons assisting with sample collection in the field, including the hunters who allowed us to sample their animals. We are also grateful to Peter Outridge, from the Canadian Geological survey, and Michael Goodsite, from the NERI, for discussing the techniques that we used. Special acknowledgement to Carine Churlaud from the Centre Commun d'Analyses (La Rochelle, France), Poul Bjerner Hansen from the University of Southern Denmark, and 
Gert Asmund, Sigga Joensen, and Lene Bruun, from the NERI, for their valuable input on the Hg analysis, and to Pierre Richard, Benoît Lebreton, and Gaël Guillou, from LIENSs (UMR 6250 CNRS-La Rochelle University, France), for their contribution and advice on the stable isotope analysis. Jeppe Møhl, Hans Baagøe, and Abdi Hedayat, from the Natural History Museum of Denmark in Copenhagen, are acknowledged for their help with collections and maceration process of mandibles. Finally, the two anonymous reviewers are thanked for their comments which added some more consistency and clarity to this paper; and Andrew Wright and Leslie Aroon Walsh are greatly acknowledged for their help and the corrections that they brought to this manuscript regarding the revisions and the use of the English language. 


\section{References}

Aguilar A, Borrell A, Pastor T. Biological factors affecting variability of persistent pollutant levels in cetaceans. J Cetacean Res Manag 1999;Special Issue 1:83-116.

AMAP. The AMAP Trends and Effects Programme: 1998-2003. Arctic Monitoring and Assessment Programme (AMAP), Report 99, 7; 2003.

Atwell L, Hobson KA, Welch HE. Biomagnification and bioaccumulation of mercury in an arctic marine food web: insights from stable nitrogen isotope analysis. Can J Fish and Aquat Sci 1998;55(5):1114-21.

Born EW, Outridge P, Riget FF, Hobson KA, Dietz R, Øien N, et al. Population substructure of North Atlantic minke whales (Balaenoptera acutorostrata) inferred from regional variation of elemental and stable isotopic signatures in tissues. J Mar Sys 2003;43(1-2):1-17.

Born EW, Teilmann J, Acquarone M, Rigét FF. Habitat use of ringed seals (Phoca hispida) in the North Water Area (North Baffin Bay). Arctic 2004;57(2):129-42.

Boutron CF, Vandal GM, Fitzgerald WF, Ferrari CP. A forty year record of mercury in central Greenland snow. Geophys Res Lett 1998;25(17):3315-8.

Brooks S, Lindberg S, Gordeev V, Christensen J, Gusev A, Macdonald R, et al. Transport pathways and processes leading to environmental exposure. In: AMAP Assessment 2002: Heavy metals in the Arctic. Oslo: Arctic Monitoring and Assessment Programme (AMAP); 2005. p. 11-41. 
Caurant F, Navarro M, Amiard JC. Mercury in pilot whales: Possible limits to the detoxification process. Sci Total Environ 1996;186(1-2):95-104.

Caurant F, Aubail A, Lahaye V, Van Canneyt O, Rogan E, López A, et al. Lead contamination of small cetaceans in European waters - the use of stable isotopes for identifying the sources of lead exposure. Mar Environ Res 2006;62(2):131-48.

Das K, Beans C, Holsbeek L, Mauger G, Berrow SD, Rogan E et al. Marine mammals from Northeast Atlantic: relationship between their trophic status as determined by $\delta^{13} \mathrm{C}$ and $\delta^{15} \mathrm{~N}$ measurements and their trace metal concentrations. Mar Environ Res 2003;56(3):349-65.

Dehn LA, Sheffield GG, Follmann EH, Duffy LK, Thomas DL, O'Hara TM. Feeding ecology of phocid seals and some walrus in the Alaskan and Canadian Arctic as determined by stomach contents and stable isotope analysis. Polar Biol 2007;30(2):167-81.

DeNiro MJ, Epstein S. Influence of diet on distribution of carbon isotopes in animals. Geochim Cosmochim Acta 1978;42(5):495-506.

Dietz R, Heide-Jørgensen M-P, Teilmann J, Valentin N, Härkönen T. Age determination in European Harbour seals Phoca vitulina. L. Sarsia 1991;76:17-21.

Dietz R, Rigét F, Johansen P. Lead, cadmium, mercury and selenium in Greenland marine animals. Sci Total Environ 1996;186(1-2):67-93. 
Dietz R, Paludan-Müller P, Agger CT, Nielsen CO. Cadmium, mercury, zinc and selenium in ringed seals (Phoca hispida) from Greenland and Svalbard. In: Heide-Jørgensen MP, Lydersen C, editors. Ringed seals in the North Atlantic. Tromsø: The North Atlantic Marine Mammal Commission, NAMMCO Scientific publications vol.1; 1998. p. 242-73.

Dietz R, Riget F, Hobson KA, Heide-Jørgensen MP, Møller P, Cleemann M, et al. Regional and inter annual patterns of heavy metals, organochlorines and stable isotopes in narwhals (Monodon monoceros) from West Greenland. Sci Total Environ 2004;331(1-3):83-105.

Eide R, Wesenberg GR, Fosse G. Mercury in primary teeth in preindustrial Norway. Scand J Dent Res 1993;101(1):1-4.

Eide R, Wesenberg GR. Mercury contents of indicators and target organs in rats after longterm, low-level, mercury vapor exposure. Environ Res 1993;61(2):212-22.

France RL. Differentiation between littoral and pelagic food webs in lakes using stable carbon isotopes. Limnol Oceanogr 1995;40(7):1310-3.

Grandjean P, Weihe P, Nielsen JB. Methylmercury: significance of intrauterine and postnatal exposures. Clin Chem 1994;40(7-II):1395-400.

Hall GEM, Pelchat P. Evaluation of a direct solid sampling atomic absorption spectrometer for the trace determination of mercury geological samples. Analyst 1997;122(9):921-4. 
Haller LA, Olmez I, Baratz R, Rabinowitz M, Douglass CW. Dentin as a possible bioepidemiologic measure of exposure to mercury. Arch Environ Contam Toxicol $1993 ; 25(1): 124-8$.

Hobson KA, Welch HE. Determination of trophic relationships within a high arctic marine food web using $\delta^{13} \mathrm{C}$ and $\delta^{15} \mathrm{~N}$ analysis. Mar Ecol Prog Ser 1992;84(1):9-18.

Hobson KA, Sease JL, Merrick RL, Piatt JF. Investigating trophic relationships of pinnipeds in Alaska and Washington using stable isotope ratios of nitrogen and carbon. Mar Mamm Sci 1997;13(1):114-32.

Hobson KA, Sease JL. Stable isotope analyses of tooth annuli reveal temporal dietary records: An example using Steller sea lions. Mar Mamm Sci 1998;14(1):116-29.

Hobson KA, Riget FF, Outridge PM, Dietz R, Born E. Baleen as a biomonitor of mercury content and dietary history of North Atlantic Minke Whales (Balaenoptera acutorostrata): combining elemental and stable isotope approaches. Sci Total Environ 2004;331(1-3):69-82.

Hohn AA. Age estimation. In: Perrin WF, Würsig B, Thewissen JGM, editors. Encyclopedia of marine mammals. Academic Press; 2002; p. 6-13.

Holst M, Stirling I, Hobson KA. Diet of ringed seals (Phoca hispida) on the east and west sides of the north water polynya, northern Baffin Bay. Mar Mamm Sci 2001;17(4):888-908. 
Kahl JDW, Martinez DA, Kuhns H, Davidson CI, Jaffrezo JL, Harris JM. Air mass trajectories to Summit, Greenland: a 44-year climatology and some episodic events. J Geophys Res-Oceans 1997;102(C12):26861-75.

Kapel FO, Christiansen J, Heide-Jørgensen MP, Härkönen T, Born EW, Knutsen LØ et al. Netting and conventional tagging used to study movements of ringed seals (Phoca hispida) in Greenland. In: Heide-Jørgensen MP, Lydersen C, editors. Ringed seals in the North Atlantic. Troms $\varnothing$ : The North Atlantic Marine Mammal Commission, NAMMCO Scientific publications vol.1; 1998. p. 211-28.

Kinghorn A, Humphries MM, Outridge P, Chan HM. Teeth as biomonitors of selenium concentrations in tissues of beluga whales (Delphinapterus leucas). Sci Total Environ 2008;402(1):43-50.

Maxwell G. Other seals of the northern hemisphere. In: Seals of the world. London: Constable. 151 pp.; 1967.

Møller P. Lipids and stable isotopes in marine food webs in West Greenland. National Environmental Research Institute, University of Aarhus, PhD thesis; 2006.

Miyazaki N. Teeth. In: Perrin WF, Würsig B, Thewissen JGM, editors. Encyclopedia of marine mammals. Academic Press; 2002; p. 1227-32. 
Newsome SD, Etnier MA, Kurle CM, Waldbauer JR, Chamberlain CP, Koch PL. Historic decline in primary productivity in western Gulf of Alaska and eastern Bering Sea: isotopic analysis of northern fur seal teeth. Mar Ecol Prog Ser 2007;332: 211-24.

Nino-Torres CA, Gallo-Reynoso JP, Galvan-Magana F, Escobar-Briones E, Macko SA.

Isotopic analysis of $\delta^{13} \mathrm{C}, \delta^{15} \mathrm{~N}$, and $\delta^{34} \mathrm{~S}$ "a feeding tale" in teeth of the longbeaked common dolphin, Delphinus capensis. Mar Mamm Sci 2006;22(4):831-46.

Outridge PM, Wagemann R, McNeely R. Teeth as biomonitors of soft tissue mercury concentrations in beluga Delphinapterus leucas. Environ Toxicol Chem 2000;19:1517-22.

Outridge PM, Hobson KA, McNeely R, Dyke A. A comparison of modern and preindustrial levels of mercury in the teeth of beluga in the Mackenzie Delta, Northwest territories, and walrus at Igloolik, Nunavut, Canada. Arctic 2002;55(2):123-32.

Outridge PM, Hobson KA, Savelle J. Long-term changes of mercury levels in ringed seal (Phoca hispida) from Amundsen Gulf, and beluga (Delphinapterus leucas) from the Beaufort Sea, western Canadian Arctic. Sci Total Environ 2009;407(23):6044-51.

Pacyna EG, Pacyna JM. Global emission of mercury from anthropogenic sources in 1995. Water Air Soil Pollut 2002;149-65.

Pacyna JM, Keeler GJ. Sources of mercury in the Arctic. Water Air Soil Pollut 1995;80(14):621-32. 
Painter S, Cameron EM, Allan R, Rouse J. Reconnaissance geochemistry and its environmental relevance. J Geochem Explor 1994;51(3):213-46.

Polischuk SC, Hobson KA, Ramsay MA. Use of stable-carbon and -nitrogen isotopes to assess weaning and fasting in female polar bears and their cubs. Can J Zool 2001;79(3):499511.

Quay PD, Tilbrook B, Wong CS. Oceanic uptake of fossil fuel $\mathrm{CO}_{2}-{ }^{13} \mathrm{C}$ evidence. Science 1992;256(5053):74-9.

R Development Core Team R: A language and environment for statistical computing. Foundation for Statistical Computing, Vienna, Austria 2008; ISBN 3-900051-07-0, URL http://www.R-project.org.

Rau GH, Sweeney RE, Kaplan IR. Plankton ${ }^{13} \mathrm{C} /{ }^{12} \mathrm{C}$ ratio changes with latitude - differences between Northern and Southern oceans. Deep Sea Res A-Oceanogr Res Papers 1982;29(8):1035-9.

Reeves RR, Stewart BS, Leatherwood S. The Sierra Club Handbook of Seals and Sirenians 1992; 359 pp.

Rigét F, Dietz R, Vorkamp K, Johansen P, Muir D. Levels and spatial and temporal trends of contaminants in Greenland biota: an updated review. Sci Total Environ 2004;331(1-3):29-52.

Rigét F, Muir D, Kwan M, Savinova T, Nyman M, Woshner V, et al. Circumpolar pattern of mercury and cadmium in ringed seals. Sci Total Environ 2005;351-2:312-22. 
Rigét F, Dietz R, Born EW, Sonne C, Hobson KA. Temporal trends of mercury in marine biota of west and northwest Greenland. Mar Pollut Bull 2007;54(1):72-80.

Siegstad H, Neve PB, Heide-Jørgensen MP, Härkönen T. Diet of the ringed seal (Phoca hispida) in Greenland. In: Heide-Jørgensen MP, Lydersen C, editors. Ringed seals in the North Atlantic. Troms $\varnothing$ : The North Atlantic Marine Mammal Commission, NAMMCO Scientific publications vol.1; 1998. p. 229-41.

Stewart REA, Stewart BE, Stirling I, Street E. Counts of growth layer groups in cementum and dentine in ringed seals (Phoca hispida). Mar Mamm Sci 1996; 12(3):383-401.

Stewart BE, Innes S, Stewart REA. Mandibular dental ontogeny of ringed seals (Phoca hispida). Mar Mamm Sci 1998; 14(2):221-31.

Tieszen LL, Boutton TW, Tesdahl KG, Slade NA. Fractionation and turnover of stable carbon isotopes in animal tissues - implications for $\delta^{13} \mathrm{C}$ analysis of diet. Oecologia 1983; 57(1-2):327.

Tvinnereim HM, Eide R, Riise T. Heavy metals in human primary teeth: some factors influencing the metal concentrations. Sci Total Environ 2000;255(1-3):21-7.

Wagemann R. Comparison of heavy metals in 2 groups of ringed seals (Phoca hispida) from the Canadian Arctic. Can J Fish and Aquat Sci 1989;46(9):1558-63. 
Wagemann R, Muir DCG. Concentrations of heavy metals and organochlorines in marine mammals of northern waters: overview and evaluation. Can Tech Rep Fish Aquat Sci No. 1279, 97 pp.; 1984.

Wagemann R, Stewart REA, Lockhart WL, Stewart BE, Povoledo M. Trace-metals and methyl mercury - associations and transfer in harp seal (Phoca groenlandica) mothers and their pups. Mar Mamm Sci 1988;4(4):339-55.

Wagemann R, Lockhart WL, Welch H, Innes S. Arctic marine mammals as integrators and indicators of mercury in the Arctic. Water Air Soil Pollut 1995;80:683-93.

Watt GR, Thrane K. Early Neoproterozoic events in East Greenland. Precamb Res 2001;110(1-4):165-84.

Zar JH. Biostatistical analysis: International edition. Pearson Education; 2009. 
Table 1. Year of capture, number of ringed seals, their mean age ( \pm standard deviation) in years, and their dental $\mathrm{Hg}$ concentrations range and mean ( \pm standard deviation) in $n g . \mathrm{g}^{-1} \mathrm{dw}$, for the two regions, Qeqertarsuaq (Central West Greenland, CWG) and Ittoqqortoormiit (Central East Greenland, CEG).

\begin{tabular}{|c|c|c|c|c|c|c|c|c|c|}
\hline \multicolumn{5}{|c|}{ Qeqertarsuaq (CWG) } & \multicolumn{5}{|c|}{ Ittoqqortoormiit, CEG } \\
\hline Year & $\mathrm{n}$ & $\begin{array}{c}\text { Mean age } \\
\pm \mathrm{sd}\end{array}$ & $\begin{array}{c}\text { Mean }[\mathrm{Hg}] \pm \\
\text { sd } \\
\end{array}$ & Range [Hg] & Year & $\mathrm{n}$ & $\begin{array}{c}\text { Mean age } \\
\pm \mathrm{sd}\end{array}$ & $\begin{array}{c}\text { Mean }[\mathrm{Hg}] \\
\pm \mathrm{sd}\end{array}$ & Range $[\mathrm{Hg}]$ \\
\hline 1982 & 20 & $3.7 \pm 3.5$ & $3.64 \pm 2.69$ & $1.29-10.99$ & 1986 & 27 & $7.8 \pm 6.6$ & $6.05 \pm 1.70$ & $3.4-10.3$ \\
\hline 1994 & 26 & $3.1 \pm 2.2$ & $1.20 \pm 0.47$ & 2.20 & 1994 & 16 & $5.7 \pm 4.0$ & $2.43 \pm 0.95$ & .75 \\
\hline 1999 & 10 & $2.6 \pm 2.8$ & $2.52 \pm 1.11$ & & & 19 & $4.6 \pm 2.7$ & $5.63 \pm 10.76$ & $1.7-49.52$ \\
\hline 2000 & 8 & $1.4 \pm 1.5$ & $2.13 \pm 0.46$ & & & 17 & $4.3 \pm 2.4$ & $5.48 \pm 2.91$ & 3.68 \\
\hline 2001 & 15 & $1.6 \pm 1.4$ & $3.26 \pm 1.51$ & 2.1 & 2001 & 20 & $6.6 \pm 6.4$ & $6.25 \pm 3.27$ & 13.73 \\
\hline 2002 & 13 & $1.4 \pm 1.2$ & $3.39 \pm 1.3$ & 2.03 & 2002 & 19 & $4.6 \pm 2.4$ & $4.91 \pm 1.49$ & $2.92-9.29$ \\
\hline 2004 & 9 & $1.0 \pm 0.9$ & $4.87 \pm 2.5$ & $2.42-10.23$ & 2004 & 26 & $4.4 \pm 4.1$ & $8.25 \pm 5.16$ & $4.55-28.58$ \\
\hline 2006 & 14 & $4.8 \pm 7.5$ & $3.94 \pm 1.91$ & $1.75-7.07$ & 2006 & 26 & $8.3 \pm 7.3$ & $5.47 \pm 10.79$ & $1.25-57.60$ \\
\hline All & 115 & $2.7 \pm 3.5$ & $2.94 \pm 1.99$ & $0.95-57.60$ & All & 170 & $6.0 \pm 5.2$ & $5.75 \pm 6.20$ & $0.43-10.99$ \\
\hline
\end{tabular}

Table 2. Analytical quality data for the customised reference material measured concurrently with the tooth samples (units in $\mu \mathrm{g} \cdot \mathrm{g}^{-1} \mathrm{dw}$ ).

\begin{tabular}{lccc}
\hline & $\mathrm{n}$ & $\begin{array}{c}\text { Hg concentration } \\
\text { mean } \pm \text { sd }\end{array}$ & $\begin{array}{c}\text { \% Relative standard } \\
\text { deviation }\end{array}$ \\
\hline AMA CCA & 8 & $0.0963 \pm 0.0035$ & 3.7 \\
AMA NERI & 10 & $0.105 \pm 0.006$ & 5.7 \\
FIMS NERI & 5 & $0.1063 \pm 0.0036$ & 3.4 \\
\hline Mean measured concentration* & 23 & $0.1023 \pm 0.0064$ & 6.3 \\
Theoretical concentration** & 1 & $0.1 \pm 0.0041$ & 4.1 \\
\hline * The mean measured concentration is the average of the Hg concentrations determined by the three sequences of analyses. \\
*** The theoretical concentration is based on the DOLT-3 certified concentration in Hg.
\end{tabular}


Table 3. Range and mean \pm standard deviation (sd) of $\delta^{15} \mathrm{~N}$ and $\delta^{13} \mathrm{C}$ values in the teeth of ringed seals from central West Greenland (CWG) and central East Greenland (CEG).

\begin{tabular}{lccccc}
\cline { 3 - 6 } & & \multicolumn{2}{c}{$\delta^{15} \mathrm{~N}(\%)$} & \multicolumn{2}{c}{$\delta^{13} \mathrm{C}(\%)$} \\
\hline All individuals & $\mathrm{n}$ & Range & Mean $\pm \mathrm{sd}$ & Range & Mean $\pm \mathrm{sd}$ \\
CWG & 101 & 12.11 to 20.26 & $15.51 \pm 1.30$ & -18.46 to -14.75 & $-16.72 \pm 0.79$ \\
CEG & 137 & 12.11 to 18.04 & $14.9 \pm 1.14$ & -18.46 to -15.73 & $-17.23 \pm 0.53$ \\
\hline
\end{tabular}

Table 4. Result matrix of the statistics (Pearson's correlation and ANOVA) testing the relations between $\delta^{15} \mathrm{~N}$ and $\delta^{13} \mathrm{C}$ values, age and $\mathrm{Hg}$ concentrations in teeth of ringed seals from central West Greenland (CWG) and central East Greenland (CEG).

\begin{tabular}{|c|c|c|c|c|c|}
\hline & $\delta^{15} \mathrm{~N} / \delta^{13} \mathrm{C}$ & Age $/ \delta^{15} \mathrm{~N}$ & Age $/ \delta^{13} \mathrm{C}$ & $\log \mathrm{Hg} / \delta^{15} \mathrm{~N}$ & $\log \mathrm{Hg} / \delta^{13} \mathrm{C}$ \\
\hline All individuals & $0.399 * * *$ & $-0.341 * * *$ & -0.028 & $-0.191 * *$ & $-0.392 * * *$ \\
\hline CWG & -0.057 & $-0.289 * *$ & $0.25 * *$ & 0.125 & -0.145 \\
\hline $\mathrm{CEG}$ & -0.011 & -0.162 & $0.417 * * *$ & 0.014 & -0.109 \\
\hline
\end{tabular}




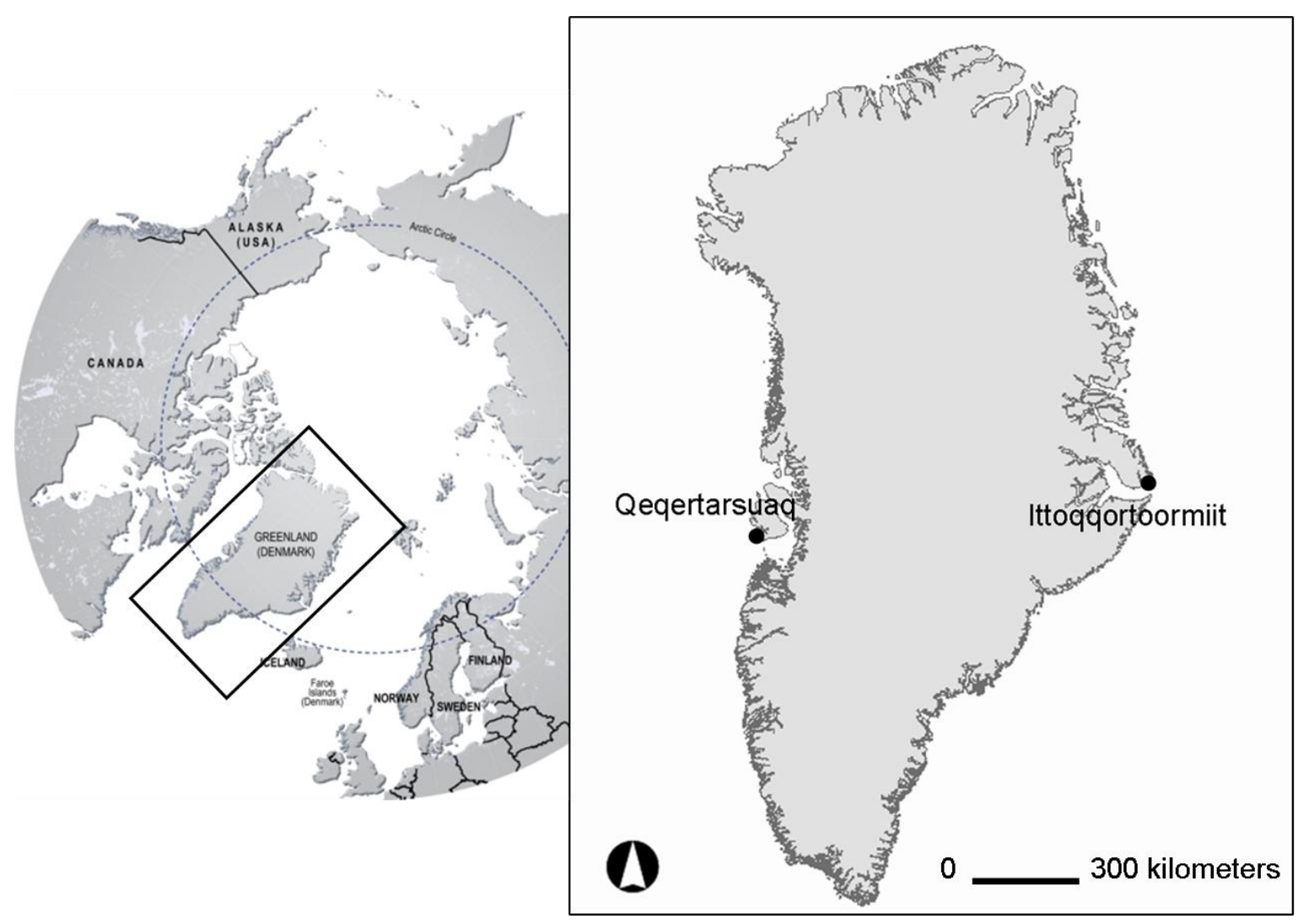

Figure 1. Map showing the two regions in Greenland from where ringed seals were sampled. 
CWG


CEG
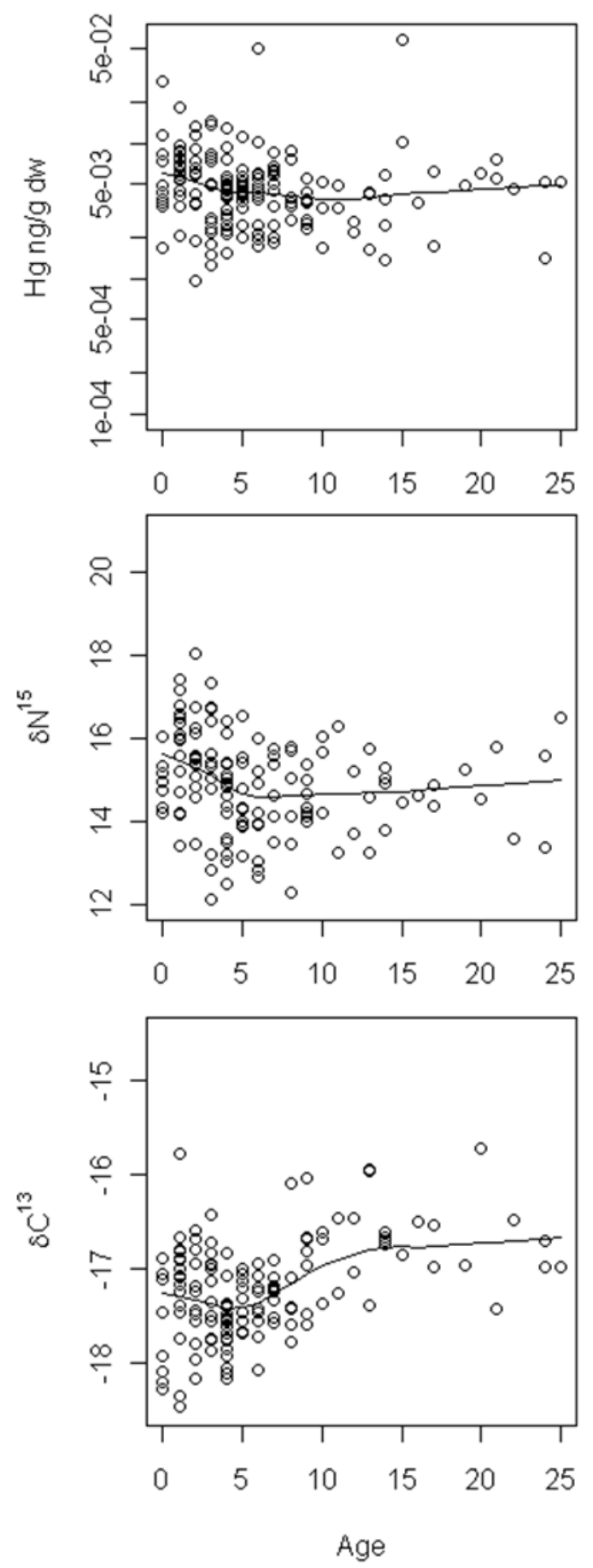

Figure 2. Age (in years) vs. $\mathrm{Hg}$ concentrations (in $n g . \mathrm{g}^{-1} \mathrm{dw}$ ), $\delta^{15} \mathrm{~N}$ and $\delta^{13} \mathrm{C}$ values (in \%o) in teeth of ringed seals from central West Greenland (CWG, left figures) and central East Greenland (CEG, right figures). The black lines are LOWESS smoother (robust, locally weighted scatterplot smoothing system based on the LOWESS algorithm). The $\mathrm{y}$-axis for $\mathrm{Hg}$ concentrations is logarithmic-scaled. 

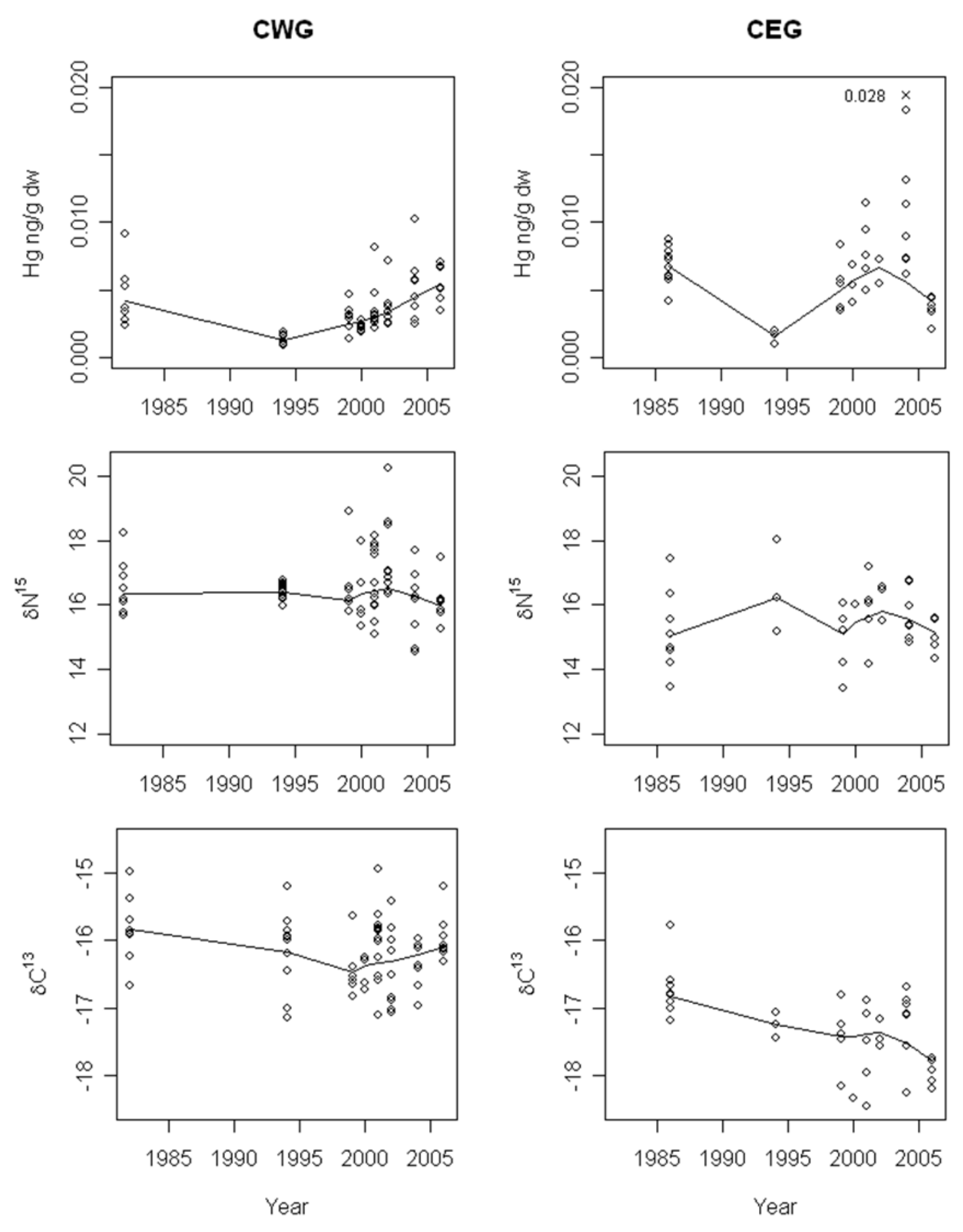

Figure 3. Temporal trend of $\mathrm{Hg}$ concentrations (in ng. ${ }^{-1} \mathrm{dw}$ ), $\delta^{13} \mathrm{C}$ and $\delta^{15} \mathrm{~N}$ values (\%o) in teeth of ringed seals from central West Greenland (CWG, left figure) and from central East Greenland (CEG, right figure) ringed seals. The smoothing lines (robust, locally weighted scatterplot smoothing system based on the LOWESS algorithm) represent the fitted non-linear trends of the values. The y-axis for $\mathrm{Hg}$ concentrations is logarithmic-scaled. 